there were many undesirable features of design and shortcomings in performance. The main improvements of the Penguin Mark II were increased mechanical reliability, personal comfort, and weather protection. The Mark II is equipped with wireless and carries five men with their essential personal survival equipment. It is heated, weather-proofed, and will float in water. It is capable of towing heavy loads and in spite of its great weight the wide tracks permit it to travel over surfaces where a man without snow shoes would sink in snow or mud.

\title{
UNITED STATES AIR FORCE RESCUE ACTIVITIES IN ALASKA
}

[Based on a note by Wilbur Forrest in the New York Herald Tribune of 14 December 1947 and information in Alaska Sportsman, Vol. 16, No. 7, 1950, p. 21, and The Times of 30 March 1950.]

An interesting consequence of United States Air Force activity in the Arctic during recent years has been the development of techniques to rescue airmen forced down and stranded in polar regions. This work has been carried out mainly by the specially trained 10th Air Search and Rescue Squadron, commanded by Colonel Bernt Balchen, U.S.A.F. The squadron, which is based on the Elmendorff Field at Anchorage, Alaska, is equipped with a miscellaneous collection of aircraft suitable for different kinds of rescue work. Detachments are based on Adak, in the Aleutian Islands; Cold Bay, at the end of the Alaskan peninsula; and on Ladd Field near Fairbanks. In addition to multi-engined amphibious aircraft and small L-5s, the squadron is equipped with DC-3s, fitted with a combination of skis and wheels, and gliders for landing on especially rough terrain.

A special unit of the squadron has been practising rescue methods on the pack ice off Point Barrow, and small L-5 aircraft have successfully landed 200 miles north of the mainland. On 21 and 22 March 1950 a C-47 aircraft, piloted by Lieutenant-Colonel Eugene $O$. Strause, made two successful landings on the pack ice about 100 miles north of Barter Island. On both days the aircraft, fitted with a combination of skis and wheels, was preceded in its landings by a glider, which was afterwards picked up and towed back to Barter Island.

In September 1947, Major-General J. H. Atkinson, commanding the United States Air Force in Alaska, decided to open a training establishment where airmen under his command might learn how to survive if they were forced down in arctic conditions. The school, known as the Arctic Polar Survival and Indoctrination School, was established at Nome in the winter of 1947-48, and placed under the command of Captain Harold Lovell Strong, United States Army. Airmen are given a six-day instructional course, consisting of three days on barren tundra and three days on sea ice. The course aims to give psychological assurance to airmen that rescue work is possible even in very adverse circumstances. It is emphasized that with the normal amount of equipment and common sense, and the proper utilization of such natural resources as may be available, they can expect to survive the experience. 
The school works in close co-operation with the 10th Air Search and Rescue Squadron, which is called upon in cases of emergency to drop sledges, dog teams, and drivers by parachute.

It has been found that dog teams are more effective than either helicopter or "Weasel" for rescue work on land, and a number of sledge dogs are kept at the school; the drivers, almost without exception, are enlisted Eskimo holding ranks up to that of sergeant. With these facilities it is claimed that there is no part of Alaska in which rescue operations are impossible.

\section{UNITED STATES AIR FORCE RESCUE FLIGHTS IN GREENLAND, 1947 AND 1948}

[Summarized from information in the National Geographic Magazine, Vol. 96, No. 4, 1949, p. 525; The Times of 20 and 29 December 1948; Manchester Guardian of 21 December 1948: and New York Times of 29 December 1948.]

In February 1947 a United States B-29 aircraft, known as the Kee-Bird, was forced down in Daugaard-Jensens Land in north-west Greenland. A rescue aircraft, piloted by Lieutenant Bobby Joe Cavenar, U.S.A.A.F., was flown from Westover Air Force Base, Massachusetts. A landing was made beside the wrecked machine and the eleven stranded members of the crew were safely removed.

On 9 December 1948 a United States C-47 transport aircraft crashed on the Greenland ice cap some 230 miles south-east of Bluie West Eight (Søndre Stromfjord), $7800 \mathrm{ft}$. above sea-level. The stranded crew of seven built shelters with blocks of snow and communications were established by means of a wireless transmitter salvaged from the aircraft: supplies were dropped by parachute, but on 14 December a B-17 Flying Fortress, with a crew of two, crash-landed while attempting a rescue. Four days later a glider was dropped to the nine stranded men, and a transport aircraft made two unsuccessful attempts to snatch the heavily laden machine from the ice. The wheels of the glider were afterwards removed, and on the third attempt it was lifted clear of the ice. Unfortunately the tow rope parted almost immediately, but a safe landing was made and the five men on board escaped injury. At this time the temperature was $-40^{\circ} \mathrm{F} .\left(-40^{\circ} \mathrm{C}\right.$.). Later attempts to lift the glider also failed, and three more airmen were forced to join the stranded party. Finally, a ski-fitted C-47 flown by Lieutenant-Colonel Emil G. Beaudry and Lieutenant Charles W. Blackwell effected a landing on 28 December. The aircraft was fitted with jet-assisted take-off equipment to minimize the hazards of a long take-off from rough snow, and the twleve rescued airmen were taken to Bluie West Eight.

\section{IONOSPHERIC STATIONS IN CANADA}

[Based on notes in Arctic Circular, Vol. 1, No. 1, 1948, p. 3-4; Vol. 2, No. 3, 1949, p. 30-32; No. 5, p. 60-63; No. 6, p. 77; Arctic. Journal of the Arctic Institute of North America, Vol. 1, No. 2, 1948, p. 137-38.]

Wireless communications in Canada are frequently disrupted by atmospheric disturbances, which cause intermittent fading and even complete inability 